THE WORKS OF WILLIAM HARVEY 
This page intentionally left blank 


\title{
THE WORKS OF
}

WI L L IAM

HARVEY

\author{
Translated by \\ Robert Willis, M.D.
}

\section{Introduction by \\ Arthur C. Guyton, M.D.}

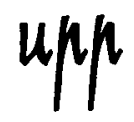

University of Pennsylvania Press

Philadelphia 


\section{UNIVERSITY OF PENNSYLVANIA PRESS \\ CLASSICS IN \\ MEDICINE AND BIOLOGY SERIES}

Edited by

Alfred P. Fishman, M.D.

William Maul Measey Professor of Medicine

University of Pennsylvania

\section{Introduction by Arthur Guyton copyright $(\mathcal{C} 1989$ by the University of Pennsylvania Press}

ALL RIGHTS RESERVED

Printed in the United States of America

\section{Library of Congress Cataloging-in-Publication Data}

Harvey, William, 1578-1657.

[Works. 1989]

The works of William Harvey / translated by Robert Willis; introduction by Arthur C. Guyton.

p. cm.- University of Pennsylvania Press classics in medicine and biology series)

Reprint. Originally published: New York : Johnson Reprint Corp., 1965.

Bibliography: p.

ISBN 0-8122-8166-7

1. Physiology-Early works to 1800 . 2. Blood-Circulation-Early works to 1800 . 3. Embryology-Early works to 1800 . I. Willis, Robert, 1799-1878. II. Title. III. Series.

QP29.H37A2 1989

612 de19

88-28081 